\title{
Thyroid hormone receptor regulates most genes independently of fibroblast growth factor 21 in liver
}

\author{
Aijun Zhang ${ }^{1}$, Douglas H Sieglaff ${ }^{1}$, Jean Philippe York ${ }^{1}$, Ji Ho Suh ${ }^{1}$, Stephen D Ayers ${ }^{1, *}$, \\ Glenn E Winnier', Alexei Kharitonenkov ${ }^{2}$, Christopher Pin ${ }^{3,4}$, Pumin Zhang ${ }^{5}$, \\ Paul Webb' ${ }^{1}$ and Xuefeng Xia ${ }^{1,6}$ \\ ${ }^{1}$ Houston Methodist Research Institute, Genomic Medicine Program, 6670 Bertner Ave, Houston, Texas 77030, USA \\ ${ }^{2}$ College of Arts and Sciences, Chemistry Department, Indiana University Bloomington, Bloomington, Indiana, USA, \\ ${ }^{3}$ Departments of Paediatrics, Oncology, and Physiology and Pharmacology, University of Western Ontario, \\ London, Ontario, Canada \\ ${ }^{4}$ Children's Health Research Institute, London, Ontario, Canada \\ ${ }^{5}$ Department of Molecular Physiology and Biophysics, Baylor College of Medicine, Houston, Texas, USA \\ ${ }^{6}$ The Third Affiliated Hospital of Guangzhou Medical University, Guangzhou, China \\ *(S D Ayers is now at Personalis Inc., Department of Genomics, Menlo Park, CA, USA)
}

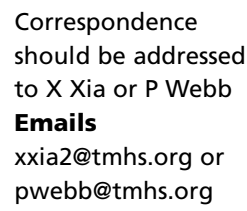

\begin{abstract}
Thyroid hormone (TH) acts through specific receptors (TRs), which are conditional transcription factors, to induce fibroblast growth factor 21 (FGF21), a peptide hormone that is usually induced by fasting and that influences lipid and carbohydrate metabolism via local hepatic and systemic endocrine effects. While TH and FGF21 display overlapping actions when administered, including reductions in serum lipids, according to the current models these hormones act independently in vivo. In this study, we examined mechanisms of regulation of FGF21 expression by $\mathrm{TH}$ and tested the possibility that FGF21 is required for induction of hepatic TH-responsive genes. We confirm that active TH (triiodothyronine $\left(T_{3}\right)$ ) and the TR $\beta$-selective thyromimetic GC1 increase FGF21 transcript and peptide levels in mouse liver and that this effect requires TR $\beta$. $\mathrm{T}_{3}$ also induces FGF21 in cultured hepatocytes and this effect involves direct actions of TR $\beta 1$, which binds a TRE within intron 2 of FGF21. Gene expression profiles of WT and Fgf21-knockout mice are very similar, indicating that FGF21 is dispensable for the majority of hepatic $T_{3}$ gene responses. A small subset of genes displays diminished $T_{3}$ response in the absence of FGF21. However, most of these are not obviously directly involved in $\mathrm{T}_{3}$-dependent hepatic metabolic processes. Consistent with these results, $\mathrm{T}_{3}$-dependent effects on serum cholesterol are maintained in the $\mathrm{Fgf21}^{-1-}$ background and we observe no effect of the Fgf21-knockout background on serum triglycerides and glucose. Our findings indicate that $T_{3}$ regulates the genes involved in classical hepatic metabolic responses independently of FGF21.
\end{abstract}

Journal of Endocrinology (2015) 224, 289-301

\section{Introduction}

Fibroblast growth factor 21 (FGF21) is one of three endocrine FGFs that influence metabolic responses via a combination of local and systemic actions. FGF21 is expressed in the liver, pancreas, and white and brown adipose tissue (Johnson et al. 2009, Fon Tacer et al. 2010, Kliewer \& Mangelsdorf 2010). Hepatic Fgf21 expression is http://joe.endocrinology-journals.org DOI: 10.1530/JOE-14-0440
(C) 2015 Society for Endocrinology Printed in Great Britain
Published by Bioscientifica Ltd 
induced by the nuclear hormone receptor peroxisome proliferator-activated receptor $\alpha$ (PPAR $\alpha)$ under fasting conditions, and secreted FGF21 peptide exerts autocrine/ paracrine effects on liver, including regulation of genes involved in lipogenesis, lipolysis, and fatty acid oxidation, as well as additional endocrine effects on other tissues (Badman et al. 2007). Administration of FGF21 to overweight and diabetic mice results in decreases in the levels of plasma triglycerides and glucose, and increases in both insulin sensitivity and thermogenesis associated with decreased body weight (Coskun et al. 2008, Berglund et al. 2009, Xu et al. 2009). Conversely, mice that lack FGF21 exhibit late-onset obesity. Thus, there is intense interest in FGF21 as a therapeutic for metabolic disorders, weight loss, and diabetes. Potentially adverse effects of FGF21 have also come to light. FGF21 is involved in integration of metabolism and bone turnover, raising the possibility that FGF21 could promote bone loss, and elevated FGF21 levels are associated with abnormal lipid profiles in coronary heart disease, raising concerns about cardiovascular events (Iglesias et al. 2012, Wei et al. 2012). Moreover, FGF21 levels become elevated in obesity and nonalcoholic fatty liver disease, indicating that serum FGF21 levels do not always correlate with an improved metabolic profile. Given these concerns, it is important to understand how to manage local production of FGF21 in desired target tissues and the consequences of changes in FGF21 concentrations.

Thyroid hormones (THs) act as master regulators of metabolism and there is evidence for interdependency of TH and FGF21 signaling pathways. TH receptors (TR $\alpha$ and TR $\beta$ ) are members of the nuclear hormone receptor family that regulate target genes in response to the main active form of $\mathrm{TH}$, triiodothyronine $\left(\mathrm{T}_{3}\right)$. TRs usually work by binding DNA-response elements (TREs) in the proximal promoters of target genes as heterodimers with retinoid $\mathrm{X}$ receptors (RXRs) but can also regulate target genes via protein-protein interactions with heterologous transcription factors (Baxter \& Webb 2009, Cheng et al. 2010, Lin et al. 2013). $T_{3}$ induces FGF21 in mouse liver and, in this study, TR $\beta$ selectively enhances FGF21 expression and promoter activity via interactions with PPAR $\alpha$ bound to PPAR $\alpha$-response elements, but does not require PPAR $\alpha$ to induce other $T_{3}$-regulated genes (Adams et al. 2010). In addition, FGF21 administration to mice reduces serum levels of the parental form of $\mathrm{TH}$, thyroxine $\left(\mathrm{T}_{4}\right)$, and $\mathrm{T}_{3}$, implying mutual regulatory dependency of these signaling systems (Domouzoglou et al. 2014). In spite of these potential relationships, key actions of FGF21 and TH appear largely independent (Domouzoglou et al. 2014). Recent assessments of administration of TH to Fgf21knockout mice have revealed no differences in serum lipids, the expression of selected $\mathrm{T}_{3}$-regulated genes in liver and brown adipose tissue, or overall energy expenditure. Conversely, FGF21 elicited similar alterations in serum lipids and gene expression in hypothyroid and euthyroid mice.

In this study, we set out to understand the mechanisms and downstream effects of TH-dependent changes in hepatic $F \& 21$ expression. We find that both $\mathrm{T}_{3}$ and the TR $\beta$-selective thyromimetic GC1 act through TR $\beta$ to directly induce FGF21 expression and that the Fgf21 locus harbors a functional TRE within intron 2 . This finding added another layer of complexity to previous studies of $\mathrm{T}_{3}$ regulation of FGF21 expression, which indicated that TR $\beta$ works primarily through PPAR $\alpha$ bound to the FGF21 promoter (Adams et al. 2010). While patterns of hepatic $T_{3}$ responses are similar in WT and Fgf21-knockout mice, similar to previous studies of a subset of hepatic genes involved in lipid metabolism (Domouzoglou \& Maratos-Flier 2011, Domouzoglou et al. 2014), we also find that optimal response of a small subset of hepatic TH-target genes requires Fgf21. These genes, however, are not obviously related to metabolic regulation and we find no changes in serum metabolic parameters in $F \& f 21$-knockout mice. Thus, our data support the idea that hepatic effects of TH on gene regulation and metabolism are largely independent of $F \& 21$.

\section{Materials and method}

\section{Mice}

All animal experiments were approved by the Animal Care and Use Committee of Houston Methodist Hospital Research Institute. Mouse strains C57BL/6, $\mathrm{ApoE}^{-/-}$, $L d l r^{-/}$, and $T R \beta^{-/-}$were purchased from The Jackson Laboratory (Bar Harbor, ME, USA) at 9 weeks of age. F\&f $21^{-1-}$ mice on a C57/BL6 background (Dutchak et al. 2012) were received from The University of Texas Southwestern Medical Center (Dallas, TX, USA). For short-term ligand treatments ( 1 and 3 days) $\mathrm{T}_{3}$, GC1, or vehicle (control) were administered to mice $(n=5)$ by oral gavage at a dose of $1 \mathrm{mg} / \mathrm{kg}$ body weight, after which, mice were killed and dissected for tissue harvesting. For long-term treatments (2 weeks), GC1 was admixed into diet at a dose of $0.8 \mathrm{mg} / \mathrm{kg}$ body weight, after which the mice were killed for collection of blood and tissue samples.

\section{Quantitative RT-PCR}

Total RNA was isolated from livers or cultured cells using the RNAeasy Kit (Qiagen) and reverse transcribed to cDNA using the ABI Reverse Transcription Kit according to the

Published by Bioscientifica Ltd 
manufacturer's instructions. Gene transcript expression was measured by quantitative RT-PCR (qPCR) (Roche LightCycler 480 II), in $20 \mu \mathrm{l}$ reactions that included cDNA (10 ng of initial RNA input), $900 \mathrm{nM}$ of each primer, PCR-grade water, and $10 \mu \mathrm{l}$ of $2 \times$ TaqMan Master Mix (Applied Biosystems). The transcript expression levels were normalized to peptidylprolyl isomerase A (PPIA) expression levels. Independent samples were prepared from five to six different mice per genotype or three separate cell culture seedings and analyzed in technical triplicates. Gene transcript abundance was assessed by the standard $\Delta \Delta C \mathrm{p}$ method and results were expressed as relative fold change compared with respective control group. Primer catalog numbers are available on request.

\section{Serum FGF21 analyses}

Mouse serum FGF21 concentrations were determined by ELISA (Phoenix Secretomics (Burlingame, CA, USA), PS00101-EK-M-1), according to the manufacturer's protocol. Serum samples of six to seven mice from each treatment were analyzed.

\section{Immunoblot analysis}

One hundred micrograms of liver were homogenized in $1 \mathrm{ml}$ homogenization buffer (10 mM Tris- $\mathrm{HCl}$ (pH 7.5), $5 \mathrm{mM}$ EDTA, $150 \mathrm{mM} \mathrm{NaCl}, 30 \mathrm{mM}$ sodium phosphate, $10 \%$ glycerol, $0.5 \%$ NP40) containing complete protease inhibitor cocktail (Roche) using a Polytron homogenizer. The homogenate was centrifuged at $14000 \boldsymbol{g}$ for $8 \mathrm{~min}$ at $4{ }^{\circ} \mathrm{C}$ and the supernatant collected for further analysis. The proteins were separated by SDS-PAGE, transferred to polyvinylidine difluoride membranes (Millipore, Billerica, MA, USA), and detected with primary FGF21 and $\beta$-actin (Sigma) antibodies at 1:1000 and 1:10 000 dilutions, respectively, and HRP-conjugated secondary antibody at 1:5000 dilution. Immunoreactive proteins were visualized using the ECL western blotting detection system (Amersham, RPN2106), and densitometry analysis was conducted with Scion Image v4.0.3.2 software.

\section{Cell culture}

HepG2 (ATCC, Bethesda, MD, USA) and HepG2-TR $\beta$ (Lin et al. 2013) cells were grown in DMEM supplemented with $10 \%$ fetal bovine serum (FBS), $100 \mathrm{U} / \mathrm{ml}$ of penicillin, $0.1 \mathrm{~g} / \mathrm{l}$ of streptomycin, and $4 \mathrm{mmol} / \mathrm{l}$ glutamine, under $95 \%$ air and $5 \% \mathrm{CO}_{2}$ at $37^{\circ} \mathrm{C}$. For cycloheximide (CHX) treatment, HepG2-TR $\beta$ cells were maintained within 10\% resin-stripped
FBS-DMEM media for $24 \mathrm{~h}$ before treatment. The cells were pretreated with $\mathrm{CHX}$ at $10 \mu \mathrm{g} / \mathrm{ml}$ for $30 \mathrm{~min}$, followed by $10 \mathrm{nM} \mathrm{T}_{3}$ incubation for $6 \mathrm{~h}$, after which RNA was collected using the RNAeasy Kit (Qiagen). For RNA interference assays, HepG2-TR $\beta$ cells were plated in 10\% resin-stripped FBSDMEM media and grown to 50\% confluency. The cells were transfected with PPAR $\alpha$ ON-TARGET plus SMART pool or negative control siRNA (Dharmacon, Waltham, MA, USA) at a $50 \mathrm{nM}$ final concentration, and $48 \mathrm{~h}$ later treated with $10 \mathrm{nM} \mathrm{T}_{3}$ or bezofibrate for $6 \mathrm{~h}$, after which RNA was collected using the RNAeasy Kit (Qiagen).

\section{Chromatin immunoprecipitation}

Chromatin immunoprecipitation (ChIP) was performed using the EZ ChIP Kits (Millipore) according to the manufacturer's instructions. Briefly, mice livers were homogenized with a hand-held homogenizer in PBS containing a broad-spectrum protease inhibitor cocktail and then cross-linked with $1 \%$ formaldehyde. The nuclei were collected by adding lysis buffer following cross-linkage, which was stopped through addition of glycine. The liver nuclear solution was sonicated with a Fisher 60 Sonic Dismembranator (Thermo Fisher Scientific, Waltham, MA, USA). The sonicated solution was incubated with anti-TR $\beta$ polyclonal antibody or control rabbit IgG (Millipore) overnight with agitation at $4{ }^{\circ} \mathrm{C}$. The TR $\beta$ antibody used for ChIP has also been used for TR $\beta$ ChIP studies of mouse cerebellum and liver (Dong et al. 2009, Paquette et al. 2011) and was originally purchased from Affinity Bioreagents (Golden, CO, USA), but was later made available through Thermo Fisher Scientific and Pierce (Grand Island, NY, USA), as PA1-213A. We have used the same antibody for western blotting analysis of TR $\beta$ expression in cell lines and mouse liver with appropriate controls for TR $\beta$ specificity shown (Ayers et al. 2014, Lammel Lindemann et al. 2014). Antibody-bound chromatin was precipitated with protein G-conjugated agarose beads, washed with gradient stringent buffers, and eluted with the elution buffer provided with the kit. The isolated DNA was analyzed by qPCR analysis using oligonucleotides corresponding to the following regions of the FGF21 locus: $F g f 21+715 /+902$, forward: 5'-CAGACTGGCCCTCAGAGAAG-3', reverse: 5'-CTCTGCCTAGGTTGGCATTC-3'. $F g f 21+3727 /+3880$ forward: 5'-CATGTGGATTCTGGGATTTG-3', reverse: 5'-GACCAGGCTGGACTCAAGTT-3'.

\section{Transient transfection}

For cloning of Fgf21-luciferase reporters, a 339-bp fragment of $F g f 21$ intron 2 was PCR amplified from C57BL/6 mouse

Published by Bioscientifica Ltd 


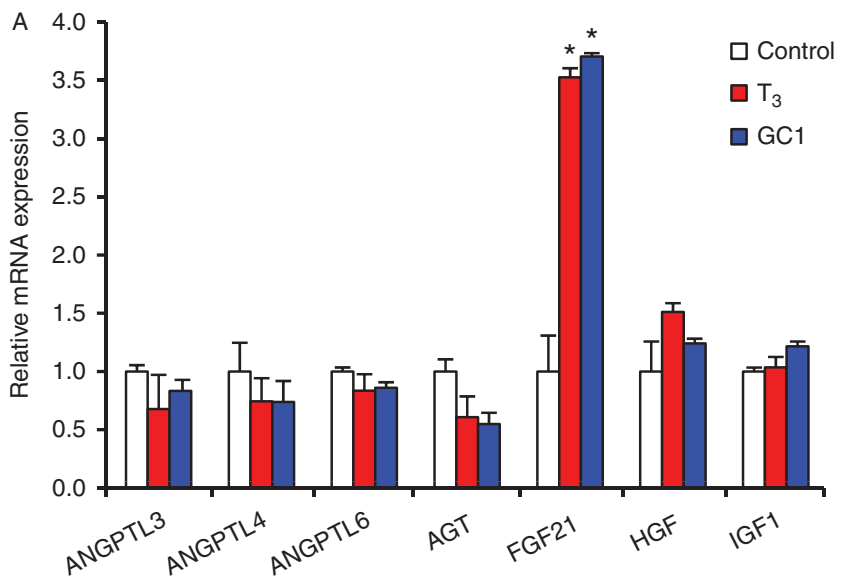

\section{Electrophoretic mobility shift assay}

Electrophoretic mobility shift assay (EMSA) was performed by incubating ${ }^{32} \mathrm{P}$-labeled oligonucleotide probes with in vitro translated $\operatorname{TR} \beta$ and $\operatorname{RXR} \alpha$. The results were visualized by autoradiography. Competition assays were performed by adding $100 \times$ molar excess of either unlabeled oligonucleotide probes (specific competitor) or unlabeled mutant oligonucleotide probe (nonspecific competitor, mutated bases are indicated in each figure).

\section{Microarray analysis}

Mouse WG-6 v2 whole-genome expression arrays were

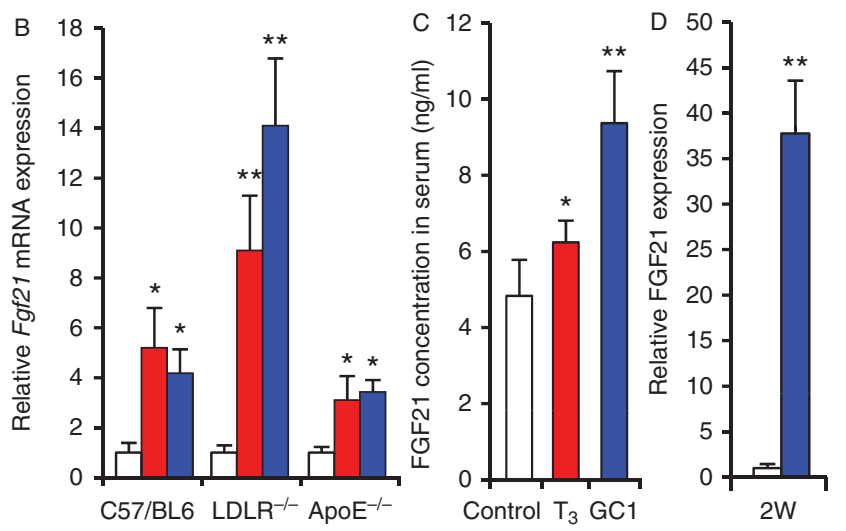
purchased from Illumina (San Diego, CA, USA), and cRNA synthesis and labeling were performed using Illumina TotalPrep-96 RNA Amplification Kit (Ambion, Austin, TX, USA), with the labeling in vitro transcription reaction performed at $37^{\circ} \mathrm{C}$ for $14 \mathrm{~h}$. Biotinylated cRNA samples were hybridized to arrays at $58^{\circ} \mathrm{C}$ for $18 \mathrm{~h}$ according to the manufacturer's protocol. Arrays were scanned using BeadArray Reader (Illumina). Unmodified microarray data obtained from GenomeStudio were background-subtracted and quantile-normalized using the lumi package (Du et al. 2008) and analyzed with the limma package (Smyth 2005) within R (R Development Core Team 2010). All analysis was corrected for multiple hypotheses testing (Benjamini \& Hochberg 1995) and effects were determined to be signi-

Figure 1

Fgf21 is upregulated in livers of $\mathrm{T}_{3}$-treated mice. (A) Results of qRT-PCR analysis of hepatic FGF21 transcript levels in WT (C57BL/6) mice treated with $\mathrm{T}_{3}$ or GC1 for $24 \mathrm{~h}$ ( $n=6 /$ group) along with other secreted hepatic factors, as follows: angiopoietin-like factors (ANGPTL) 3, 4, and 6; angiotensinogen (AGT), hepatocyte growth factor (HGF), insulin-like growth factor 1 (IGF1). (B) Hepatic Fgf21 mRNA levels in LDL receptor knockout $\left(L d l r^{-I-}\right)$ and apolipoprotein E-knockout $\left(A p o E^{-1-}\right)$ mice treated with $\mathrm{T}_{3}$ or $\mathrm{GC} 1$ for $24 \mathrm{~h}$ ( $n=6 /$ group). (C) Circulating levels of FGF21 in $\mathrm{Ldlr}^{-1-}$ mice treated with $\mathrm{T}_{3}$ or GC1 for $24 \mathrm{~h}$ ( $n=6 /$ group). (D) Hepatic Fgf21 mRNA levels in Ldlr ${ }^{-1-}$ mice 28 days following GC1 treatment ( $n=6 /$ group). Statistical significance of the observed changes is denoted by single or double asterisks, which indicate and refers to $P<0.05$ or $P<0.01$ respectively.

gDNA and cloned into the BglII and HindIII sites of pGL4-23. Positive clones were confirmed through sequencing. For luciferase assays, HepG2-TR $\beta 1$ cells $\left(2 \times 10^{5}\right.$ cells/well) were seeded into six-well plates $12 \mathrm{~h}$ before transfection of $1 \mu \mathrm{g} /$ well of Fgf21-luciferase reporter constructs and $0.1 \mu \mathrm{g} /$ well of Renilla-luciferase control plasmid using Fugene 6 transfection reagent. Twentyfour hours post transfection, cells were incubated with $10 \mathrm{nM} \mathrm{T}_{3}$ for another $24 \mathrm{~h}$, after which luciferase activity was determined using the Promega Dual Luciferase Assay Kit following the manufacturer's instructions. ficant when there was a greater than or equal to twofold increase/decrease relative to the control and they had an adjusted $P$ value $<0.05$. Raw microarray data sets have been deposited in the NCBI Gene Expression Omnibus (GEO)

A

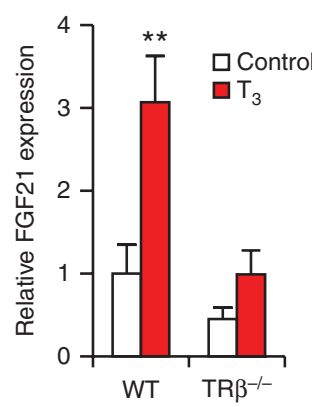

Figure 2

Fgf21 induction requires TR $\beta$. (A) qRT-PCR analysis of hepatic Fgf21 transcript levels in WT (C57BL/6) mice treated with $\mathrm{T}_{3}$ for $24 \mathrm{~h}$ or $\operatorname{Tr} \beta^{-1-}$ knockout mice ( $n=6 /$ group). (B) Western blotting analysis of hepatic FGF21 protein levels in WT and $\operatorname{Tr} \beta^{-1-}$ mice with representative gel images at the top and quantitation below. The statistical significance of the observed changes is denoted by double asterisks, which indicate $P<0.01$. 

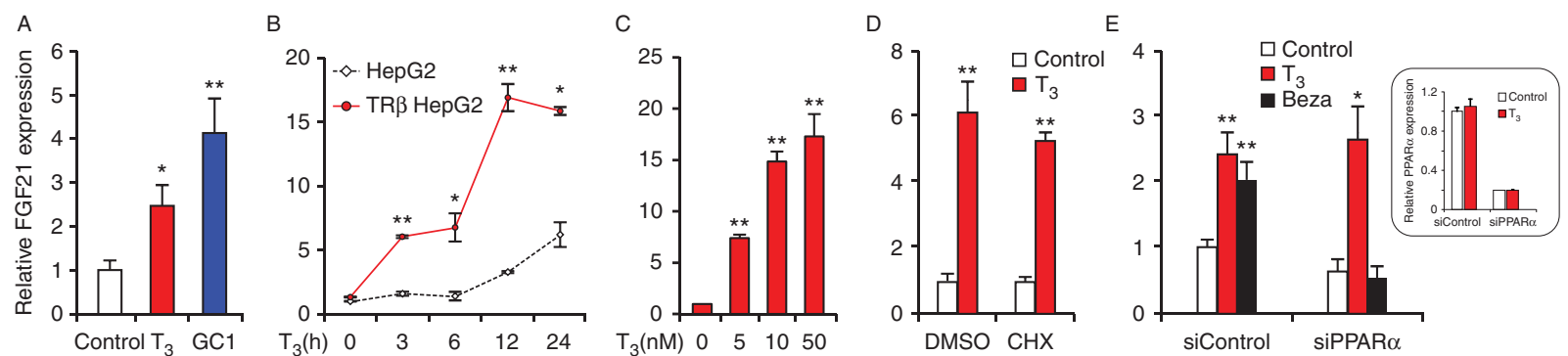

Figure 3

TR $\beta$-dependent induction of FGF21 in cultured cells. (A) FGF21 mRNA levels in HepG2 cells treated with GC1 (10 nM), $T_{3}(10 \mathrm{nM})$ or vehicle for $24 \mathrm{~h}$ $(n=4)$. (B) Expression levels of FGF21 mRNA in HepG2 cells that express exogenous TR $\beta 1$ or in parental HepG 2 cells examined by RT-qPCR at different time points after $\mathrm{T}_{3}$ induction $(n=4)$. (C) $\mathrm{T}_{3}$ concentration dependence of induction of FGF21 mRNA in HepG2 cells that expressed exogenous TR $\beta$ was examined by RT-qPCR for various concentrations of $T_{3}$ for $24 \mathrm{~h}(n=4)$. (D) $\mathrm{T}_{3}$ induction of FGF21 mRNA is insensitive to CHX. Cells

database under accession number GSE58062. Microarray data was also validated through qPCR (TaqMan) analysis, showing excellent correlation $R^{2}=0.85(n=59)$.

\section{Data analysis and statistics}

All values are expressed as mean \pm s.E.M. Statistical analyses were performed using GraphPad Prism Version 5.0 Software (GraphPad, Inc., San Diego, CA, USA). Data were analyzed by Student's $t$-test, Mann-Whitney $U$ test, or one-way ANOVA, where $P$ values $<0.05$ were considered to be statistically significant.

\section{Serum metabolites}

Serum aliquots were sent to the comparative pathology laboratory of Baylor College of Medicine (Houston, TX, USA) for serum chemistry analysis.

\section{Results}

\section{$\mathrm{T}_{3}$ and GC1 induce Fgf21 in liver in a TR $\beta$-dependent manner}

We examined the effects of acute $(24 \mathrm{~h})$ treatment of male C57BL/6 mice with $\mathrm{T}_{3}$ or the thyromimetic GC1 on hepatic Fgf21 expression. Fgf21 mRNA was induced by both ligands, an effect not observed for genes that encode other secreted hepatic factors (Fig. 1A). Similar effects of TR ligands on $F g f 21$ expression were seen in two mouse models of dyslipidemia ( $A p o E^{-/-}$and $L d l r^{-/-}$) (Fig. 1B) and FGF21 induction was accompanied by increases in circulating FGF21 peptide in serum (Fig. 1C). The selective were pretreated with $\mathrm{CHX}$ for 30 min, followed by $\mathrm{T}_{3}$ for $6 \mathrm{~h}$. (E) PPAR $\alpha$ knockdown does not affect $T_{3}$ response of FGF21 in HepG2 cells. qRT-PCR analysis of FGF21 transcript levels after treatment of HepG2-TR $\beta$ cells with bezofibrate or $T_{3}$ for $2 \mathrm{~h}$. Results are shown in the presence of control scrambled siRNA or PPAR $\alpha$-specific siRNA. Knockdown levels of PPAR $\alpha$ transcripts are shown in the inset. The statistical significance of the observed changes is denoted by single or double asterisks, which indicate $P<0.05$ and $P<0.01$ respectively.

thyromimetic GC1 also elicited increases in hepatic Fgf21 expression, which persisted for at least 2 weeks with continuous treatment (Fig. 1D). Optimal hepatic $\mathrm{T}_{3}$ induction of FGF21 required TR $\beta$, the predominant TR subtype in liver (Fig. $2 \mathrm{~A}$ and $\mathrm{B}$ ). Thus, $\mathrm{T}_{3}$ acts primarily through TR $\beta$ to induce hepatic Fgf21 expression.

\section{TR $\beta$ directly induces Fgf21 in cultured cells}

To define the mechanisms of TH-dependent induction of hepatic $F g f 21$ expression, we examined the response of $F g f 21$ mRNA to $T_{3}$ or GC1 in human HepG 2 cells that stably express TR $\beta$ (Lin et al. 2013). We observed induction of FGF21 following short-term treatment with either ligand (Fig. 3A). This effect persisted over several time points (Fig. 3B and
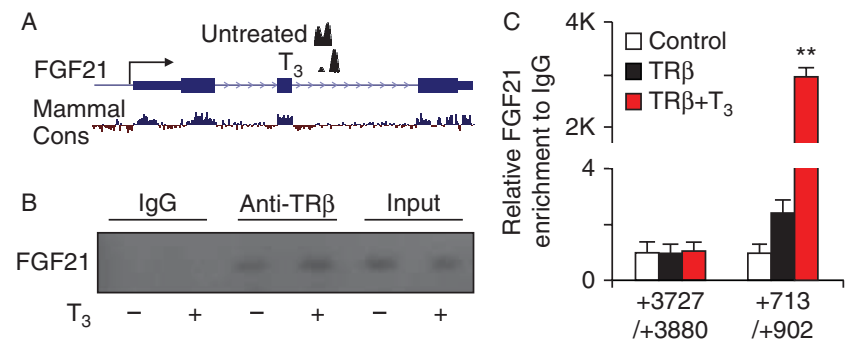

Figure 4

A TR $\beta$-binding site in the FGF21 second intron. (A) Results of ChIP-Seq analysis with HepG2-TR $\beta$ cells showing binding events in the FGF21 second intron. (B) Representative gel showing results of ChIP analysis with an anti-TR $\beta 1$ antibody to verify binding within FGF21 intron 2 along with an IgG control. (C) qRT-PCR analysis of ChIP experiments showing specific binding of TR $\beta 1$ to the FGF21 intron 2 in native mouse liver. Immunoprecipitations were carried out with either TR $\beta$ antibodies or control IgG, and immunopurified DNA was analyzed with primers flanking intron 2 of FGF21 ( +715 to 902) or a control region $(+3727$ to +3880$)(n=4)$. The statistical significance of the observed changes is denoted by double asterisks, which indicate $P<0.01$. 
results not shown). A modest $\mathrm{T}_{3}$ response was also observed in parental HepG2 cells after extended $\mathrm{T}_{3}$ treatment (Fig. 3B); this delayed effect resembles the kinetics of $T_{3}$ induction of other bona fide hepatic TR-target genes in this cell type and is probably a consequence of low levels of TR $\beta$ that are present in these cells (Yuan et al. 2012). $\mathrm{T}_{3}$-dependent FGF21 induction exhibited classical dose dependence with maximal activation with $10 \mathrm{nM}$ hormone (Fig. 3C), implying that this $\mathrm{T}_{3}$ effect was TR-dependent, and was maintained after pretreatment with the protein synthesis inhibitor $\mathrm{CHX}$, implying a direct transcriptional effect of TR (Fig. 3D). Interestingly, the effects of TR $\beta$ on FGF21 expression were not absolutely dependent on PPAR $\alpha$ in HepG2 (Fig. 3E). Although induction of $F g f 21$ mRNA by the PPAR $\alpha$ ligand bezofibrate was abrogated by a PPAR $\alpha$-specific siRNA that reduced PPAR $\alpha$ transcript levels by $80 \%$ (inset), the $\mathrm{T}_{3}$ response was unaffected.

\section{A functional TRE in the Fgf21 second intron}

To determine whether TR $\beta$ might bind the Fgf21 locus independently of $\operatorname{PPAR} \alpha$, we consulted a published ChIP-chip dataset and our own preliminary ChIP-Seq results. Results of recent studies have indicated the
A

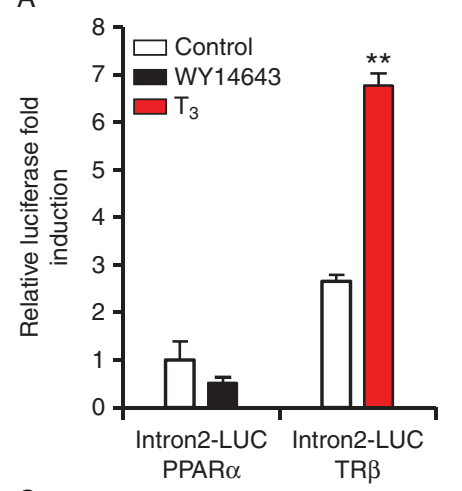

$B$

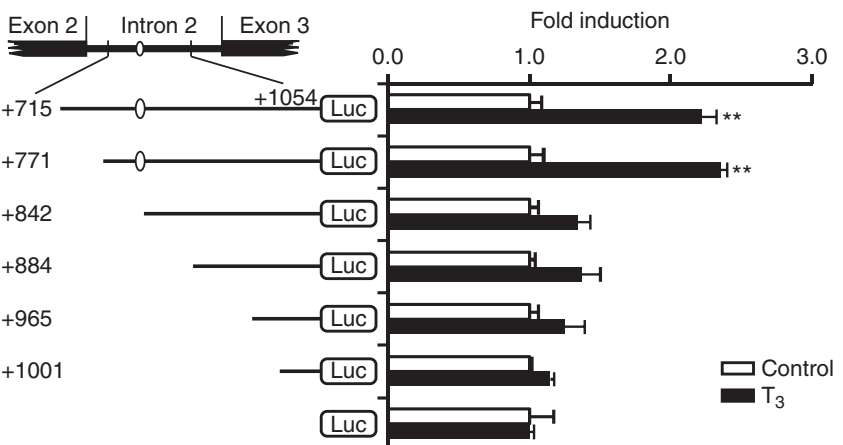

C

WT 5' -GAACTGTAACCCTGTACCTGACCTAACCTCT-3'

MUT 5' -GAACTGTAACCCTGTACCTGAaATAACCTCT-3'

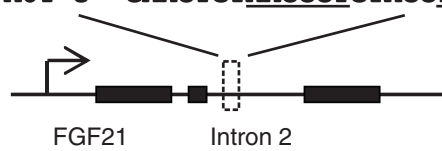

$\mathrm{D}$

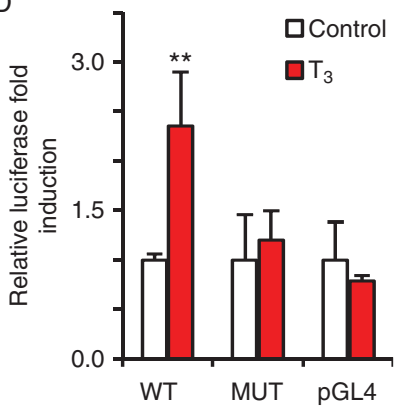

E

TR $\beta$

FGF21-WT

FGF21-Mut

$50 \times$ Comp

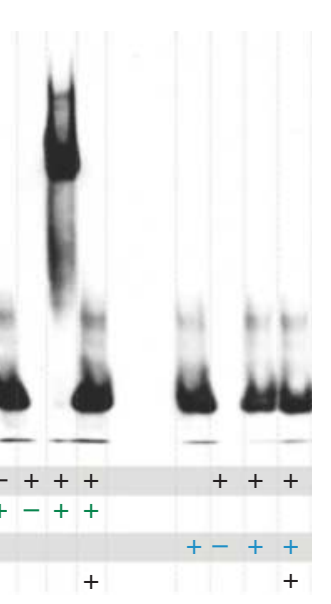

\section{Figure 5}

An intronic TRE in the FGF21 locus. (A) Reporter assays were performed in HepG2-TR $\beta 1$ cells co-transfected with a reporter construct harboring intron 2 of FGF21 in the presence of PPAR $\alpha$ or TR $\beta$ expression plasmid. The cells were

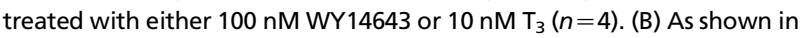
Fig. 5A, results of luciferase assays performed with a variety of reporter genes bearing intron 2 truncations are shown in the schematic diagram. (C) Diagrammatic representation of the FGF21 promoter within the reporter vector (the region that displayed enrichment within the ChIP-assay). The FGF21 promoter used in our studies contains binding sites for TR $\beta$. The TRE determined to mediate the TR $\beta$-response is also shown, as indicated by truncation and mutant analysis. (D) As shown in Fig. 5A, HepG2-TR $\beta 1$ cells http://joe.endocrinology-journals.org DOI: $10.1530 / J O E-14-0440$
() 2015 Society for Endocrinology Printed in Great Britain co-transfected with a reporter construct harboring intron 2 of FGF21 or TRE-mutant reporter constructs or control vector PGL4 in the presence of TR $\beta$ expression plasmid. The cells were treated with either vehicle or $10 \mathrm{nM} \mathrm{T}_{3}$ $(n=4)$. (E) Electrophoretic mobility shift assay (EMSA) depicting TR $\beta$ binding to the discovered TRE. The response elements were measured by mixing $100 \mathrm{ng}$ of purified TR $\beta$ (DBD-LBD) with 1 pM of biotin-labeled double-stranded oligonucleotide corresponding to +715 to +1054 of FGF21. Binding specificity of the regulatory region was verified with competition experiments in which 50 -fold molar excess of unlabeled $+715 /+1054$ oligomer or mutantTRE $+715 /+1054$ oligomer $(n=4)$. The statistical significance of the observed changes is denoted by double asterisks, which indicate $P<0.01$. 
presence of an intronic TR $\beta$-binding peak within the Fgf21 locus in mouse cerebellum (Dong et al. 2009) and we later confirmed the existence of this peak in the data derived from our own ChIP-Seq analysis of TR $\beta$-binding events in HepG2 cells (Fig. 4A) (Ayers et al. 2014). We verified TR $\beta$ binding at this location with conventional ChIP-PCR performed on human HepG2-TR $\beta$ cells (Fig. 4B) and on native mouse liver (Fig. 4C).

Cloned sequences corresponding to the second intron of human FGF21 conferred $\mathrm{T}_{3}$ responsiveness upon a luciferase reporter (Fig. 5A). There was no response to PPAR $\alpha$ ligand (WY14643). Deletion mapping indicated that important $\mathrm{T}_{3}$-responsive elements lay between the intronic sequences +771 and +842 downstream of the F\&f21 transcriptional start site (Fig. 5B). This region of the mouse gene harbored a degenerate nonconsensus TRE (DR-5) with one well conserved half site (AGGTCA; reverse strand TCCAGT) (Fig. 5C). Mutation of the putative TRE blocked the responses to $\mathrm{T}_{3}$ of the Fgf21-dependent luciferase reporter (Fig. 5D). Furthermore, the putative TRE bound bacterially expressed TR $\beta$ in EMSA and this interaction was abolished by mutation of the AGGTCA sequence or an excess of WT oligonucleotide (Fig. 5E).

\section{Altered hepatic $\mathrm{T}_{3}$-responses in $\mathrm{Fgf21^{-/- }}$ mice}

$\mathrm{As}_{3}$ induces FGF21 in liver, and secreted FGF21 peptide may exert autocrine/paracrine effects upon gene expression in hepatocytes, we determined whether $\mathrm{T}_{3}$ regulated the same genes in the livers of WT and euthyroid $F g f 21^{-/-}$mice using Illumina BeadArray analysis. More than 500 gene transcripts displayed significant response (greater than or equal to twofold with and adjusted $P$ value $<0.05$ ) to a 3-day $\mathrm{T}_{3}$ treatment in WT mice, in accordance with previous studies. In general, $\mathrm{T}_{3}$-dependent gene regulation patterns were similar in both WT and Fgf21-knockout mice and the majority of $\mathrm{T}_{3}$ responses differed by not more than $50 \%$ (black points located within the dotted lines that delimit a twofold difference between WT and $F g f 21^{-/-}$mice) (Fig. 6A).

We detected two clusters of genes with altered $\mathrm{T}_{3}$ response in the $F g f 21^{-/-}$background (red points, outside of dotted delimiting lines). One group (Table 1, 31 genes) exhibited diminished $\mathrm{T}_{3}$-dependent activation in the Fgf $21^{-1-}$ background, and the other altered group (Table 2, 23 genes) displayed diminished $\mathrm{T}_{3}$-dependent repression. These altered responses to $\mathrm{T}_{3}$ were readily reproduced in independent high-throughput qRT-PCR experiments (Fig. 6B). Examples of such genes with diminished responses to $\mathrm{T}_{3}$ in the $F g f 21$-knockout mice include Dio1, Insig2, Cdkn1, and Glut1 (Fig. 6C, full gene
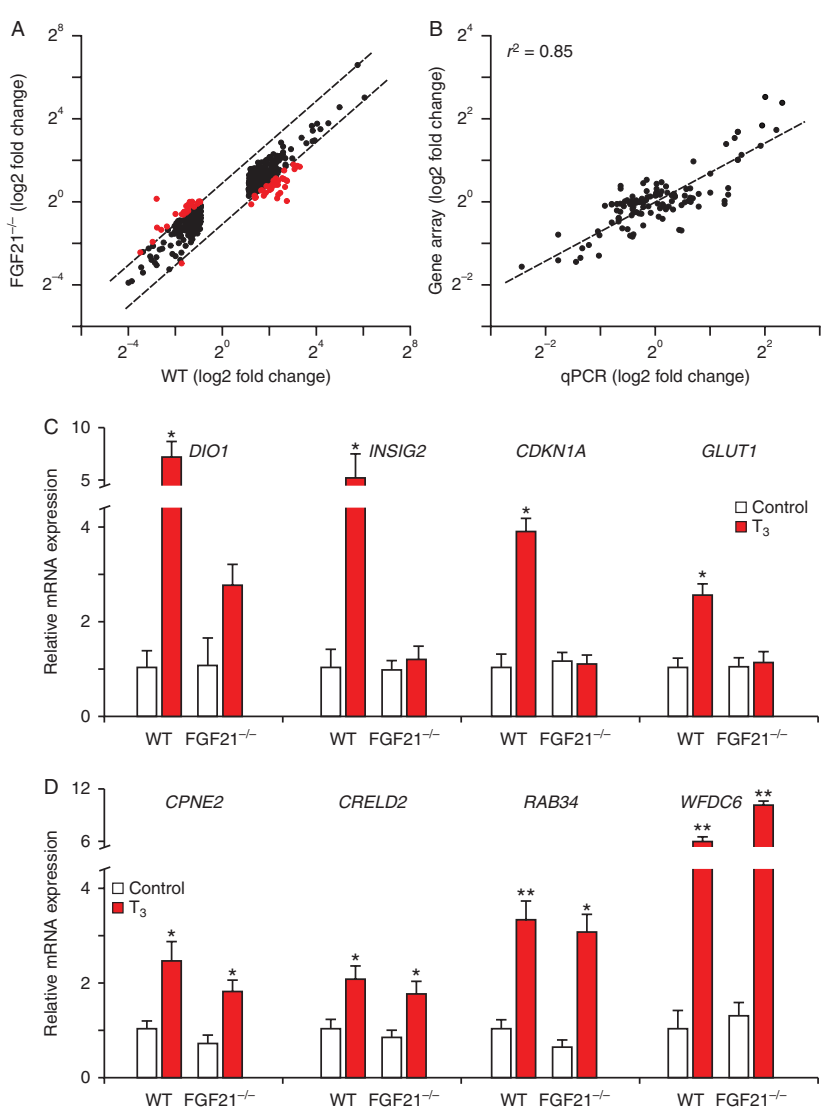

Figure 6

Similar patterns of $T_{3}$ responses in WT and Fgf21-knockout mice. (A) Scatter plots of $T_{3}$ responses in livers of WT and Fgf21-knockout mice treated with $\mathrm{T}_{3}$ for 3 days. Dots represent genes that were induced or repressed at least twofold by $T_{3}$ treatment with an adjusted $P$ value of $<0.05$. Dotted lines represent a twofold deviation from WT values. (B) QPCR validation of the microarray data. $R^{2}=0.85(n=59)$. (C) Representative qPCR verification of genes that display diminished responses to $\mathrm{T}_{3}$ in the $\mathrm{Fgf21^{-1- }}$ background. (D) Representative qPCR verification of genes that display unchanged responses to $T_{3}$ in the $F g f 21^{-1-}$ background. The statistical significance of the observed changes is denoted by single or double asterisks, which indicate $P<0.05$ and $P<0.01$ respectively.

names in Table 1). Genes that displayed similar levels of $\mathrm{T}_{3}$ response in both strains include Cpne2, Rab34, Creld2, and $W f d c 6$, as identified in our previous studies (Lin et al. 2013) (Fig. 6D). Thus, targeted ablation of Fgf21 in the mouse germ line did not result in the global inhibition of a large percentage of hepatic $T_{3}$ responses, but FGF21 was required for induction of a small subset of $\mathrm{T}_{3}$-regulated genes.

We could not perceive many obvious relationships between genes that display altered responses to $T_{3}$ in the Fof21-knockout mice and canonical hepatic metabolic process regulated by $\mathrm{TH}$ (Tables 1,2 , and 3 ). Results of ingenuity pathway analysis (IPA) indicated that the gene subsets that showed altered $\mathrm{T}_{3}$ response in the $\mathrm{F} \& 21$ knockout background might affect the action of vitamin C,

Published by Bioscientifica Ltd. 
Table 1 Positively $T_{3}$-regulated genes influenced by Fgf21 knockout

\begin{tabular}{|c|c|c|}
\hline Probe_ID & Symbol & Entrez gene name \\
\hline ILMN_2874352 & Cyp17A1 & Cytochrome P450, family 17 , subfamily A \\
\hline ILMN_2647234 & Dio1 & Deiodinase, iodothyronine, type I \\
\hline ILMN_2813830 & $N t 5 e$ & $5^{\prime}$-nucleotidase, ecto (CD73) \\
\hline ILMN_3009501 & Kcnk1 & Potassium channel, subfamily $K$, member 1 \\
\hline ILMN_1241350 & Vsig4 & $\begin{array}{l}\text { V-set and immunoglobulin domain } \\
\text { containing } 4\end{array}$ \\
\hline ILMN_1239959 & E030018b13rik & RIKEN CDNA E030018B13 gene \\
\hline ILMN_2619620 & $C 1 q b$ & $\begin{array}{l}\text { Complement component } 1, \mathrm{q} \\
\text { subcomponent, B chain }\end{array}$ \\
\hline ILMN_2715840 & $C 1 q c$ & $\begin{array}{l}\text { Complement component } 1, \mathrm{q} \\
\text { subcomponent, } \mathrm{C} \text { chain }\end{array}$ \\
\hline ILMN_2775030 & Folr2 & Folate receptor 2 (fetal) \\
\hline ILMN_2528155 & Loc227995 & $\begin{array}{l}\text { Predicted gene 13607, actin-like } \\
6 \mathrm{~A} \text { pseudogene }\end{array}$ \\
\hline ILMN_2878071 & Lyz1/Lyz2 & Lysozyme 2 \\
\hline ILMN_1234858 & Insig2 & Insulin-induced gene 2 \\
\hline ILMN_2671923 & Ly86 & Lymphocyte antigen 86 \\
\hline ILMN_1252636 & $M m d 2$ & $\begin{array}{l}\text { Monocyte to macrophage differentiation- } \\
\text { associated } 2\end{array}$ \\
\hline ILMN_2925653 & Ear2 & $\begin{array}{l}\text { Eosinophil-associated, ribonuclease A } \\
\text { family, \# } 2\end{array}$ \\
\hline ILMN_2634083 & Cdkn1a & $\begin{array}{l}\text { Cyclin-dependent kinase inhibitor 1A } \\
\text { (p21, CIP1) }\end{array}$ \\
\hline ILMN_1216880 & Emr1 & $\begin{array}{l}\text { EGF-like module containing, mucin-like, } \\
\text { hormone receptor-like } 1\end{array}$ \\
\hline ILMN_2640346 & P2ry13 & $\begin{array}{l}\text { Purinergic receptor P2Y, } \\
\text { G-protein-coupled, } 13\end{array}$ \\
\hline ILMN_2785648 & $\mathrm{Cd} 207$ & CD207 molecule, langerin \\
\hline ILMN_2533376 & Mmp27 & Matrix metallopeptidase 27 \\
\hline ILMN_2752524 & Paqr9 & $\begin{array}{l}\text { Progestin and adipoQ receptor family } \\
\text { member IX }\end{array}$ \\
\hline ILMN_2524986 & Ear3 & $\begin{array}{l}\text { Eosinophil-associated, ribonuclease A } \\
\text { family, \#3 }\end{array}$ \\
\hline ILMN_2948296 & Wfdc12 & WAP four-disulfide core domain 12 \\
\hline ILMN_2819319 & Rrm2 & Ribonucleotide reductase $\mathrm{M} 2$ \\
\hline ILMN_1241695 & Ms4a6a & $\begin{array}{l}\text { Membrane-spanning 4-domains, } \\
\text { subfamily A, member } 6 \mathrm{~A}\end{array}$ \\
\hline ILMN_2896170 & Apcs & Amyloid P component, serum \\
\hline ILMN_3118707 & Sla & Src-like-adaptor \\
\hline ILMN_2548010 & Hopx & HOP homeobox \\
\hline ILMN_2788073 & Hmox1 & Heme oxygenase (decycling) 1 \\
\hline ILMN_2761585 & $2400009 \mathrm{b08RIK}$ & RIKEN CDNA 2400009B08 gene \\
\hline ILMN_2728300 & $M d m 1$ & Mdm1 nuclear protein homolog (mice) \\
\hline ILMN_1258159 & Glut1 & Glucose transporter 1 \\
\hline
\end{tabular}

\begin{tabular}{|c|c|c|c|}
\hline \multicolumn{2}{|c|}{ Fold change } & \multicolumn{2}{|c|}{ Adjusted $P$ value } \\
\hline WT & $F g f 21 \mathrm{KO}$ & WT & Fgf21KO \\
\hline 8.861 & 3.110 & 0.000 & 0.029 \\
\hline 8.268 & 3.229 & 0.023 & 0.227 \\
\hline 7.634 & 2.870 & 0.001 & 0.060 \\
\hline 7.393 & 3.370 & 0.003 & 0.050 \\
\hline 6.151 & 1.941 & 0.016 & 0.420 \\
\hline 6.088 & -1.005 & 0.020 & 0.998 \\
\hline 6.041 & 1.988 & 0.010 & 0.343 \\
\hline 5.785 & 1.596 & 0.009 & 0.540 \\
\hline 5.643 & 2.751 & 0.002 & 0.039 \\
\hline 5.618 & 2.070 & 0.021 & 0.368 \\
\hline 5.506 & 2.081 & 0.009 & 0.265 \\
\hline 5.022 & 1.302 & 0.035 & 0.830 \\
\hline 4.760 & 1.954 & 0.004 & 0.185 \\
\hline 4.749 & 1.231 & 0.011 & 0.824 \\
\hline 4.691 & 1.715 & 0.025 & 0.499 \\
\hline 4.595 & 1.083 & 0.013 & 0.947 \\
\hline 4.462 & 1.711 & 0.022 & 0.466 \\
\hline 4.249 & 2.000 & 0.005 & 0.158 \\
\hline 4.242 & 1.781 & 0.006 & 0.260 \\
\hline 4.132 & 1.960 & 0.025 & 0.319 \\
\hline 3.988 & 1.724 & 0.045 & 0.505 \\
\hline 3.869 & 1.493 & 0.028 & 0.599 \\
\hline 3.706 & 1.438 & 0.020 & 0.601 \\
\hline 3.687 & 1.627 & 0.000 & 0.100 \\
\hline 3.376 & 1.641 & 0.020 & 0.380 \\
\hline 3.291 & 1.301 & 0.043 & 0.761 \\
\hline 3.113 & 1.191 & 0.023 & 0.824 \\
\hline 2.970 & 1.422 & 0.016 & 0.491 \\
\hline 2.882 & 1.411 & 0.005 & 0.357 \\
\hline 2.409 & 1.109 & 0.020 & 0.870 \\
\hline 2.386 & 1.185 & 0.003 & 0.597 \\
\hline 1.580 & 1.087 & 0.041 & 0.870 \\
\hline
\end{tabular}

the complement pathway, and other processes (Table 3 and results not shown). Similar biological functions were predicted through Genecodis analysis (Tabas-Madrid et al. 2012) (not shown). More directed queries in which we utilized IPA function pathway analysis to probe for the association of defined hepatic metabolic pathways with the $\mathrm{T}_{3}$ /FGF21-dependent gene subset revealed the connections of several members of this gene set with different aspects of lipid metabolism, amino acid metabolism, and carbohydrate metabolism (Table 4). Inspection of these relationships did not allow us to generate many obvious predictions about the influences of these genes upon local hepatic and systemic metabolism (see 'Discussion').

Given that there were weak associations of the $\mathrm{T}_{3}$ /FGF21-dependent gene set with classical $\mathrm{T}_{3}$-dependent hepatic metabolic pathways, we determined whether F\&f21-knockout influenced the levels of serum metabolites under the conditions of our experiment (Fig. 7). Previously, treatment with $\mathrm{T}_{3}$ and a thyromimetic has been shown to result in rapid reductions in serum cholesterol levels in WT mice (Lin et al. 2012, Lammel Lindemann et al. 2014). While we were able to reproduce this effect with short $\mathrm{T}_{3}$ 
Table 2 Negatively $T_{3}$-regulated genes influenced by Fgf21 knockout

\begin{tabular}{|c|c|}
\hline Probe_ID & Symbol \\
\hline ILMN_2852624 & Hamp/Hamp2 \\
\hline ILMN_1253233 & Dsg1c \\
\hline ILMN_2976211 & Cyp2b23 \\
\hline ILMN_2796472 & VIdlr \\
\hline ILMN_1232758 & Gm3065 \\
\hline ILMN_1214219 & Col27a 1 \\
\hline ILMN_1230145 & $A c v r 2 b$ \\
\hline ILMN_2565942 & Flnb \\
\hline ILMN_1256423 & Ranbp3I \\
\hline ILMN_1218441 & Slc23a3 \\
\hline ILMN_2875737 & Cyp2d6 \\
\hline ILMN_2523012 & Meg3 \\
\hline ILMN_2625233 & 9130230l23rik \\
\hline ILMN_1213804 & Lrp4 \\
\hline ILMN_2624328 & Adamts7 \\
\hline ILMN_1239872 & 5830473c10rik \\
\hline ILMN_1227319 & Vwce \\
\hline ILMN_1247135 & Znf276 \\
\hline ILMN_2764325 & Bricd5 \\
\hline ILMN_2587761 & Kif1b \\
\hline ILMN_2954098 & Lgals6 \\
\hline ILMN_2718600 & Nfyb \\
\hline ILMN_2622891 & C12orf43 \\
\hline
\end{tabular}

\begin{tabular}{l} 
Entrez gene name \\
\hline Hepcidin antimicrobial peptide \\
Desmoglein 1 gamma \\
Cytochrome P450, family 2, subfamily b, \\
polypeptide 23 \\
Very-LDL receptor \\
Predicted gene 3065 \\
Collagen, type XXVII, alpha 1 \\
Activin A receptor, type IIB \\
Filamin B, beta \\
RAN-binding protein 3 -like \\
Solute carrier family 23, member 3 \\
Cytochrome P450, family 2 , subfamily D, \\
polypeptide 6 \\
Maternally expressed 3 \\
RIKEN cDNA 9130230 L23 gene \\
LDL receptor-related protein 4 \\
ADAM metallopeptidase with thrombos- \\
pondin type 1 motif, 7 \\
RIKEN cDNA 5830473 C10 gene \\
Von Willebrand factor C and EGF domains \\
Zinc finger protein 276 \\
BRICHOS domain containing 5 \\
Kinesin family member $1 B$ \\
Lectin, galactose-binding, soluble 6 \\
Nuclear transcription factor Y, beta \\
Chromosome 12 open reading frame 43 \\
\end{tabular}

\begin{tabular}{|c|c|c|c|}
\hline \multicolumn{2}{|c|}{ Fold change } & \multicolumn{2}{|c|}{ Adjusted $P$ value } \\
\hline WT & Fgf21KO & WT & Fgf21KO \\
\hline-11.73 & -5.569 & 0.006 & 0.049 \\
\hline-8.159 & -3.932 & 0.002 & 0.029 \\
\hline-7.294 & 1.075 & 0.022 & 0.970 \\
\hline-7.191 & -2.436 & 0.011 & 0.253 \\
\hline-4.219 & -1.550 & 0.010 & 0.480 \\
\hline-3.491 & -1.564 & 0.001 & 0.189 \\
\hline-3.352 & -1.575 & 0.032 & 0.488 \\
\hline-3.277 & -1.451 & 0.038 & 0.605 \\
\hline-3.274 & -1.440 & 0.009 & 0.452 \\
\hline-3.073 & -1.479 & 0.030 & 0.519 \\
\hline-2.945 & -1.313 & 0.022 & 0.655 \\
\hline-2.936 & -1.143 & 0.033 & 0.879 \\
\hline-2.890 & -1.395 & 0.026 & 0.559 \\
\hline-2.767 & -1.030 & 0.020 & 0.975 \\
\hline-2.635 & -1.154 & 0.002 & 0.713 \\
\hline-2.597 & -1.026 & 0.011 & 0.975 \\
\hline-2.440 & -1.212 & 0.011 & 0.662 \\
\hline-2.209 & -1.095 & 0.007 & 0.838 \\
\hline-2.202 & -1.089 & 0.036 & 0.902 \\
\hline-2.135 & -1.021 & 0.033 & 0.980 \\
\hline-2.065 & -1.024 & 0.011 & 0.969 \\
\hline-2.061 & -1.027 & 0.005 & 0.956 \\
\hline-2.059 & -1.028 & 0.044 & 0.973 \\
\hline
\end{tabular}

treatments (Fig. 7A), it was unaltered in the $F g f 21$-knockout background. $\mathrm{No} \mathrm{T}_{3}$ - or Fgf21-dependent changes in serum triglyceride or glucose levels were detected during the course of this treatment (Fig. 7B and C).

\section{Discussion}

PPAR $\alpha$-dependent induction of FGF21 is required for changes in expression of genes that are involved in the fasting response in liver, and secreted hepatic Fgf21 influences local hepatocyte metabolism and communicates information from liver to other tissues to coordinate fasting responses. Thus, FGF21 has attracted attention as a possible therapeutic to modulate metabolic disease. In this study, we verified previous observations which indicate that $\mathrm{T}_{3}$ induces hepatic FGF21 production (Adams et al. 2010, Domouzoglou et al. 2014), and further dissected the mechanism of this effect and tested the possibility that FGF21 is required for $\mathrm{T}_{3}$-dependent changes in local hepatic $\mathrm{T}_{3}$ responses. Our results therefore support the concept that $\mathrm{T}_{3}$ and FGF21 signaling pathways exhibit mutual regulatory dependence, but function largely independently (Domouzoglou et al. 2014).

$\mathrm{T}_{3}$ acts through TR $\beta$ to directly induce FGF21 expression. We extended previous studies (Adams et al. 2010,
Domouzoglou et al. 2014) to show that sustained TR-dependent induction of FGF21 is elicited by a selective TR $\beta$ modulator and is dependent on TR $\beta$. Furthermore, similar effects were also observed in a human liver cell line (HepG2), in which FGF21 induction was amplified in the presence of exogenous TR $\beta 1$, and $T_{3}$-dependent induction of FGF21 was also detectable in the presence of low endogenous levels of TR $\beta 1$ in this cell type (Yuan et al. 2012). Thus, the capacity for $T_{3}$ regulation of hepatic FGF21 production is conserved in humans and in cultured cells of hepatic origin. Finally, TR regulation of FGF21

Table 3 IPA canonical pathway analysis of $\mathrm{T}_{3} / \mathrm{FGF} 21$-dependent genes

\begin{tabular}{|c|c|c|c|}
\hline $\begin{array}{l}\text { Ingenuity canonical } \\
\text { pathways }\end{array}$ & $\begin{array}{c}-\log \\
(P \text { value })\end{array}$ & Ratio & Molecules \\
\hline $\begin{array}{l}\text { Antioxidant action } \\
\text { of vitamin C }\end{array}$ & 2.89 & 0.027 & $\begin{array}{l}\text { HMOX1, } \\
\text { SLC23A3, } \\
\text { PLA2G7 }\end{array}$ \\
\hline Complement system & 2.61 & 0.057 & C1QC, C1QB \\
\hline Phospholipases & 2.14 & 0.030 & HMOX1, PLA2G7 \\
\hline $\begin{array}{l}\text { Bladder cancer } \\
\text { signaling }\end{array}$ & 1.77 & 0.021 & MMP27, CDKN1A \\
\hline $\begin{array}{l}\text { Pancreatic adenocar- } \\
\text { cinoma signaling }\end{array}$ & 1.62 & 0.016 & HMOX1, CDKN1A \\
\hline
\end{tabular}

Published by Bioscientifica Ltd. http://joe.endocrinology-journals.org DOI: $10.1530 / J O E-14-0440$
C 2015 Society for Endocrinology Printed in Great Britain 
Table 4 IPA function pathway analysis of metabolic pathway association with $T_{3} / F G F 21$-dependent genes

Function and pathway
Lipid Metabolism
Concentration of cholesterol
Efflux of cholesterol
Accumulation of triacylglycerol
Conversion of lipid
Quantity of steroid
Amino acid metabolism
Carbohydrate metabolism
Insulin-dependent diabetes mellitus

\section{Number of molecules}

4
2
2
3
5
2
3
6

\begin{tabular}{l}
\hline $\boldsymbol{P}$ value \\
\hline \\
0.0051 \\
0.0192 \\
0.0139 \\
0.0053 \\
0.0067 \\
0.0030 \\
0.0037 \\
0.0012 \\
\hline
\end{tabular}

Molecules

Cdkn1a, Dio1, P2ry13, Vldlr

Apcs, VIdlr

Insig2, Vldlr

Cyp17a1, Cyp2d6, Hmox1

Cdkn1a, Cyp17a1, Dio1, P2ry13, Vldlr

Cdkn1a, Dio1

Lyz1/Lyz2, Nt5e, Pla2g7

Col27a1, Ly86, Lyz1/Lyz2, Ms4a6a, Nt5e, P2ry13 exhibits an appropriate $\mathrm{T}_{3}$ dose response and is not affected by the protein synthesis inhibitor CHX, implying a direct effect of $\mathrm{T}_{3}$ through TRs.

While TRs do not bind to the Fgf21 proximal promoter, the results of studies by our own group and others indicate that TREs are often located within introns or the $3^{\prime}$ downstream region of target genes (Chatonnet et al. 2013, Gagne et al. 2013, Ayers et al. 2014, Ramadoss et al. 2014). We therefore searched published databases of TRE localization and noted that the mouse Fgf21 locus harbors a TR-binding site in intron 2. This binding site was first detected in a study of TR-binding events near of $\mathrm{T}_{3}$-target genes in cerebellum (Dong et al. 2009), which we later confirmed by our own genome wide assessment of TR $\beta 1$-binding events that utilized an engineered human HepG2 cell line that expresses exogenous TR $\beta 1$ (Ayers et al. 2014). We verified TR localization with human and mouse intron 2 using traditional ChIP-PCR approaches in HepG2 and native mouse liver and identified a functional TRE in this region of the mouse gene. We therefore suggest that TRs act through this intronic TRE to activate FGF21 expression in HepG2 cells and that this effect is independent of PPAR $\alpha$ signaling.

While our results indicate that TR can bind to a functional TRE in FGF21 intron 2, we emphasize that they do not contradict the results of previous studies which indicate that TRs cooperate with PPAR $\alpha$ to enhance FGF21 proximal promoter activity (Adams et al. 2010). Unlike the FGF21 proximal promoter, the putative FGF21 intronic TRE does not respond to PPAR $\alpha$ ligands. Furthermore, bezofibrate activation of the human FGF21 gene is abolished by PPAR $\alpha$ knockdown in HepG 2 cells, with the $\mathrm{T}_{3}$ response unaffected by PPAR $\alpha$ knockdown. Thus, $\mathrm{T}_{3}$ can activate the FGF21 gene independently of PPAR $\alpha$. However, we also verified that TR $\beta$ and PPAR $\alpha$ cooperate to elicit additive increases in FGF21-promoter-dependent luciferase reporter activity in transient transfections (results not shown). In the light of this study (Adams et al. 2010) and other suggestions that TRs cooperate with PPARs to regulate gene expression (Lu \& Cheng 2010), we suspect that TRs bound to the downstream intronic TRE can communicate with PPAR $\alpha$ to regulate FGF21 expression. This idea leads to the prediction that $\mathrm{T}_{3}$ regulation of FGF21 could be influenced by changes in $\operatorname{PPAR} \alpha$ activity and it will be interesting to see whether dietary conditions or administration of PPAR $\alpha$ ligands could alter the patterns of hepatic $T_{3}$ regulation of FGF21 or hepatic gene response in general.

As FGF21 acts in an autocrine/paracrine fashion to regulate hepatic target genes involved in metabolic responses (Inagaki et al. 2007), we also tested the hypothesis that $\mathrm{T}_{3}$-dependent regulation of hepatic gene expression programs would require FGF21. Specifically, we used an unbiased approach to determine whether responses to $\mathrm{T}_{3}$ of any hepatic genes was diminished or abrogated in a mouse strain with a targeted deletion of the $F g f 21$ gene locus. While $\mathrm{T}_{3}$ regulates hundreds of genes in the livers of euthyroid mice, many with important roles in $\mathrm{T}_{3}$-regulation of metabolic responses, there were limited differences in $\mathrm{T}_{3}$ response patterns in WT and $F g f 21^{-/-}$mice. During our studies, a group led by Maratos-Flier et al. examined $\mathrm{T}_{3}$
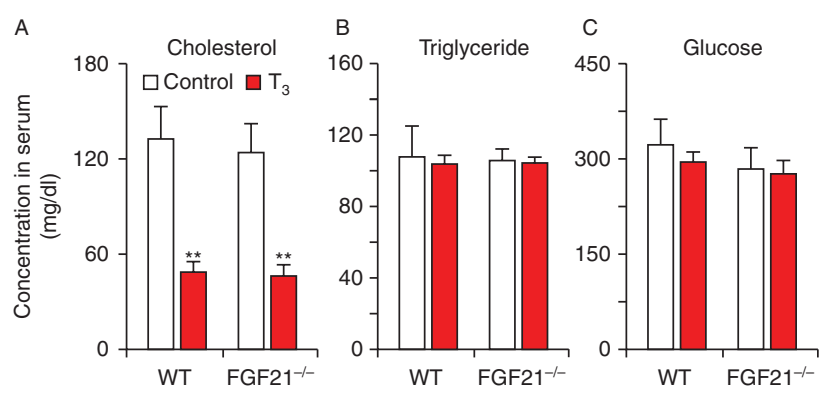

\section{Figure 7}

Analysis of serum metabolites in WT and Fgf21-knockout mice. (A) total serum cholesterol, (B) triglycerides, (C) glucose in WT and $\mathrm{Fgf21}^{-1-}$ mice after 3-day $T_{3}$ treatment. The statistical significance of the observed changes is denoted by double asterisks, which indicate $P<0.01$.

Published by Bioscientifica Ltd. 
regulation of metabolic parameters in $F g f 21$-knockout mice and the effects of administered FGF21 in hypothyroid and euthyroid mouse backgrounds (Domouzoglou et al. 2014). Results of this study revealed that $\mathrm{T}_{3}$ and FGF21-dependent effects upon serum and hepatic lipid levels, thermogenesis and energy metabolism, and selected $\mathrm{T}_{3}$ and FGF21 target genes are almost completely independent of the other hormone signaling system. Our transcriptome-wide gene expression studies extend and lend further support to this idea, and moreover, our own investigation of the effects of FGF21 and $T_{3}$ upon the levels of serum metabolites confirms that $\mathrm{T}_{3}$-dependent reductions in total serum cholesterol are completely independent of FGF21.

We detected a small subset of hepatic genes that displayed diminished responses to $\mathrm{T}_{3}$ in the $F g f 21^{-/-}$ background. In principle, such genes could be indirect targets that lie downstream of the FGF21 peptide, or FGF21 could be a permissive factor for induction of direct TR targets, analogous to the hepatic PPAR $\alpha /$ FGF21 feedforward loop established under fasting conditions in which FGF21 activation prolongs PPAR $\alpha$-dependent responses (Badman et al. 2007, Inagaki et al. 2007). While we have not determined the mechanisms of these effects, we suspect that the latter mechanism is at play at least in regulation of Dio1, which contains bona fide TREs within its proximal promoter (Zhang et al. 1998). Perhaps more surprising, however, was that $\mathrm{T}_{3} / \mathrm{FGF} 21$-dependent genes were associated with complement activation and the cell cycle and that many classical $\mathrm{T}_{3}$-regulated genes involved in cholesterol metabolism (Lin et al. 2012, Lammel Lindemann et al. 2014), fatty acid synthesis, $\beta$-oxidation, and gluconeogenesis (Singh et al. 2013, Suh et al. 2013, Thakran et al. 2013) did not appear in this list. The significance of the dual $\mathrm{T}_{3} / \mathrm{FGF} 21$ dependency displayed by this gene subset is not clear and requires further investigation.

We recognize that the notion that $\mathrm{T}_{3}$ and FGF21 regulate hepatic metabolic response independently of each other must remain qualified for several reasons. We analyzed $\mathrm{T}_{3}$-dependent changes in gene expression and serum lipid parameters after $72 \mathrm{~h}$ treatment. While this is long enough to obtain significant elevations of hepatic and serum FGF21 levels, it is possible that interactions between TR and FGF21-dependent pathways could emerge over longer treatment times. Furthermore, our studies were performed in euthyroid mice treated with $\mathrm{T}_{3}$ and not hypothyroid mice. Thus, it is possible that some $\mathrm{T}_{3}$ - and FGF21-responsive genes with key roles in metabolic response could be fully induced at $T_{3}$ concentrations observed in euthyroid mice (data shown in Lin et al. (2013)). Arguing against these possibilities, however, is the failure of the Maratos-Flier group also to identify defects in TR-dependent changes in metabolic parameters and gene expression in FGF21 knockouts over time courses of more than 1 week and in hypothyroid mice with varying levels of $\mathrm{T}_{3}$ (Domouzoglou et al. 2014).

It also remains possible that some members of the $\mathrm{T}_{3}$ /FGF21-responsive gene subset could exert hard to predict effects upon metabolic responses. We attempted a more exhaustive effort to define the association of the $\mathrm{T}_{3} / \mathrm{FGF} 21$ responsive gene subset with classical metabolic pathways and discovered possible association of genes with various aspects of lipid, amino acid, and carbohydrate metabolic pathways and insulin-dependent diabetes mellitus (Table 4). For example, DIO1 encodes a product that catalyzes the conversion of $\mathrm{T}_{4}$ to $\mathrm{T}_{3}$ and therefore will alter local $\mathrm{TH}$ levels and, potentially, TR actions upon key genes involved in cholesterol metabolism. INSIG2 is an inhibitor of sterol response element-binding protein (SREBP) activation and changes in levels of this transcription factor could result in widespread secondary alterations in the expression patterns of genes that regulate lipid metabolism. While it is conceivable that altered cooperation of TH and FGF21 at these, and other, genes could ultimately result in changes in systemic cholesterol and lipid levels, such effects were not obvious over the course of our study (Fig. 7). At present our results are most consistent with the notion that $\mathrm{T}_{3}$ dependent hepatic gene regulation patterns are largely independent of FGF21 signaling.

\section{Declaration of interest}

The authors declare that there is no conflict of interest that could be perceived as prejudicing the impartiality of the research reported.

\section{Funding}

This study was supported by NIH RC4 DK090849 (P W) and National Natural Science Foundation of China No. 81270868 (X X).

\section{Author contribution statement}

$X X$ and $P$ W designed the experiments; A Z, J P Y, J H S and S D A performed the research; G E W, D H S, A K, C P and P Z contributed reagents/analytical tools and; analyzed data; and $\mathrm{XX}$ and $\mathrm{P} \mathrm{W}$ wrote the paper.

\section{Acknowledgements}

The authors wish to honor the memory of John D Baxter (deceased) whose insights into thyroid hormone inspired this study. They thank Dr Steven A Kliewer who provided us the FGF21-knockout mice for this study.

Published by Bioscientifica Ltd. 


\section{References}

Adams AC, Astapova I, Fisher FM, Badman MK, Kurgansky KE, Flier JS, Hollenberg AN \& Maratos-Flier E 2010 Thyroid hormone regulates hepatic expression of fibroblast growth factor 21 in a PPAR $\alpha$ dependent manner. Journal of Biological Chemistry 285 14078-14082. (doi:10.1074/jbc.C110.107375)

Ayers S, Switnicki MP, Angajala A, Lammel J, Arumanayagam AS \& Webb P 2014 Genome-wide binding patterns of thyroid hormone receptor $\beta$. PLOS ONE 9 e81186. (doi:10.1371/journal.pone.0081186)

Badman MK, Pissios P, Kennedy AR, Koukos G, Flier JS \& Maratos-Flier E 2007 Hepatic fibroblast growth factor 21 is regulated by PPAR $\alpha$ and is a key mediator of hepatic lipid metabolism in ketotic states. Cell Metabolism 5 426-437. (doi:10.1016/j.cmet.2007.05.002)

Baxter JD \& Webb P 2009 Thyroid hormone mimetics: potential applications in atherosclerosis, obesity and type 2 diabetes. Nature Reviews. Drug Discovery 8 308-320. (doi:10.1038/nrd2830)

Benjamini Y \& Hochberg Y 1995 Controlling the false discovery rate: a practical and powerful approach to multiple testing. Journal of the Royal Statistical Society. Series B (Methodological) 57 289-300. (doi:10.2307/2346101)

Berglund ED, Li CY, Bina HA, Lynes SE, Michael MD, Shanafelt AB, Kharitonenkov A \& Wasserman DH 2009 Fibroblast growth factor 21 controls glycemia via regulation of hepatic glucose flux and insulin sensitivity. Endocrinology 150 4084-4093. (doi:10.1210/ en.2009-0221)

Chatonnet F, Guyot R, Benoit G \& Flamant F 2013 Genome-wide analysis of thyroid hormone receptors shared and specific functions in neural cells. PNAS 110 E766-E775. (doi:10.1073/pnas.1210626110)

Cheng SY, Leonard JL \& Davis PJ 2010 Molecular aspects of thyroid hormone actions. Endocrine Reviews 31 139-170. (doi:10.1210/ er.2009-0007)

Coskun T, Bina HA, Schneider MA, Dunbar JD, Hu CC, Chen Y, Moller DE \& Kharitonenkov A 2008 Fibroblast growth factor 21 corrects obesity in mice. Endocrinology 149 6018-6027. (doi:10.1210/en.2008-0816)

Domouzoglou EM \& Maratos-Flier E 2011 Fibroblast growth factor 21 is a metabolic regulator that plays a role in the adaptation to ketosis. American Journal of Clinical Nutrition 93 901S-905S. (doi:10.3945/ajcn. 110.001941)

Domouzoglou EM, Fisher FM, Astapova I, Fox EC, Kharitonenkov A, Flier JS, Hollenberg AN \& Maratos-Flier E 2014 Fibroblast growth factor 21 and thyroid hormone show mutual regulatory dependency but have independent actions in vivo. Endocrinology 155 2031-2040. (doi:10.1210/en.2013-1902)

Dong H, Yauk CL, Rowan-Carroll A, You SH, Zoeller RT, Lambert I \& Wade MG 2009 Identification of thyroid hormone receptor binding sites and target genes using ChIP-on-chip in developing mouse cerebellum. PLoS ONE 4 e4610. (doi:10.1371/journal.pone.0004610)

Du P, Kibbe WA \& Lin SM 2008 lumi: a pipeline for processing Illumina microarray. Bioinformatics 24 1547-1548. (doi:10.1093/bioinformatics/ btn224)

Dutchak PA, Katafuchi T, Bookout AL, Choi JH, Yu RT, Mangelsdorf DJ \& Kliewer SA 2012 Fibroblast growth factor-21 regulates PPAR $\gamma$ activity and the antidiabetic actions of thiazolidinediones. Cell 148 556-567. (doi:10.1016/j.cell.2011.11.062)

Fon Tacer K, Bookout AL, Ding X, Kurosu H, John GB, Wang L, Goetz R, Mohammadi M, Kuro-o M, Mangelsdorf DJ et al. 2010 Research resource: comprehensive expression atlas of the fibroblast growth factor system in adult mouse. Molecular Endocrinology 24 2050-2064. (doi:10.1210/me.2010-0142)

Gagne R, Green JR, Dong H, Wade MG \& Yauk CL 2013 Identification of thyroid hormone receptor binding sites in developing mouse cerebellum. BMC Genomics 14 341. (doi:10.1186/1471-2164-14-341)

Iglesias P, Selgas R, Romero S \& Diez JJ 2012 Biological role, clinical significance, and therapeutic possibilities of the recently discovered metabolic hormone fibroblastic growth factor 21. European Journal of Endocrinology 167 301-309. (doi:10.1530/EJE-12-0357)

Inagaki T, Dutchak P, Zhao G, Ding X, Gautron L, Parameswara V, Li Y, Goetz R, Mohammadi M, Esser V et al. 2007 Endocrine regulation of the fasting response by PPAR $\alpha$-mediated induction of fibroblast growth factor 21. Cell Metabolism 5 415-425. (doi:10.1016/j.cmet. 2007.05.003)

Johnson CL, Weston JY, Chadi SA, Fazio EN, Huff MW, Kharitonenkov A, Koester A \& Pin CL 2009 Fibroblast growth factor 21 reduces the severity of cerulein-induced pancreatitis in mice. Gastroenterology 137 1795-1804. (doi:10.1053/j.gastro.2009.07.064)

Kliewer SA \& Mangelsdorf DJ 2010 Fibroblast growth factor 21: from pharmacology to physiology. American Journal of Clinical Nutrition 91 254S-257S. (doi:10.3945/ajcn.2009.28449B)

Lammel Lindemann JA, Angajala A, Engler DA, Webb P \& Ayers SD 2014 Thyroid hormone induction of human cholesterol $7 \alpha$-hydroxylase (Cyp7a1) in vitro. Molecular and Cellular Endocrinology 388 32-40. (doi:10.1016/j.mce.2014.02.003)

Lin JZ, Martagon AJ, Hsueh WA, Baxter JD, Gustafsson JA, Webb P \& Phillips KJ 2012 Thyroid hormone receptor agonists reduce serum cholesterol independent of the LDL receptor. Endocrinology 153 6136-6144. (doi:10.1210/en.2011-2081)

Lin JZ, Sieglaff DH, Yuan C, Su J, Arumanayagam AS, Firouzbakht S, Cantu Pompa JJ, Reynolds FD, Zhou X, Cvoro A et al. 2013 Gene specific actions of thyroid hormone receptor subtypes. PLoS ONE 8 e52407. (doi:10.1371/journal.pone.0052407)

Lu C \& Cheng SY 2010 Thyroid hormone receptors regulate adipogenesis and carcinogenesis via crosstalk signaling with peroxisome proliferatoractivated receptors. Journal of Molecular Endocrinology 44 143-154. (doi:10.1677/JME-09-0107)

Paquette MA, Dong H, Gagne R, Williams A, Malowany M, Wade MG \& Yauk CL 2011 Thyroid hormone-regulated gene expression in juvenile mouse liver: identification of thyroid response elements using microarray profiling and in silico analyses. BMC Genomics 12634. (doi:10.1186/1471-2164-12-634)

Ramadoss P, Abraham BJ, Tsai L, Zhou Y, Costa-e-Sousa RH, Ye F, Bilban M, Zhao K \& Hollenberg AN 2014 Novel mechanism of positive versus negative regulation by thyroid hormone receptor $\beta 1$ (TR $\beta 1$ ) identified by genome-wide profiling of binding sites in mouse liver. Journal of Biological Chemistry 289 1313-1328. (doi:10.1074/jbc. M113.521450)

R Development Core Team 2010 R: A language and environment for statistical computing. R Foundation for Statistical Computing, Vienna, Austria. ISBN 3-900051-07-0, URL http://www.R-project.org/.

Singh BK, Sinha RA, Zhou J, Xie SY, You SH, Gauthier K \& Yen PM 2013 FoxO1 deacetylation regulates thyroid hormone-induced transcription of key hepatic gluconeogenic genes. Journal of Biological Chemistry $\mathbf{2 8 8}$ 30365-30372. (doi:10.1074/jbc.M113.504845)

Smyth GK 2005 Limma: linear models for microarray data. In Bioinformatics and Computational Biology Solutions using $R$ and Bioconductor, pp 397-420. Eds R Gentleman, V Carey, S Dudoit, $R$ Irizarry \& W Huber. New York: Springer.

Suh JH, Sieglaff DH, Zhang A, Xia X, Cvoro A, Winnier GE \& Webb P 2013 SIRT1 is a direct coactivator of thyroid hormone receptor $\beta 1$ with gene-specific actions. PLOS ONE 8 e70097. (doi:10.1371/journal.pone. 0070097)

Tabas-Madrid D, Nogales-Cadenas R \& Pascual-Montano A 2012 GeneCodis3: a non-redundant and modular enrichment analysis tool for functional genomics. Nucleic Acids Research 40 W478-W483. (doi:10.1093/nar/gks402)

Thakran S, Sharma P, Attia RR, Hori RT, Deng X, Elam MB \& Park EA 2013 Role of sirtuin 1 in the regulation of hepatic gene expression by thyroid hormone. Journal of Biological Chemistry 288 807-818. (doi:10.1074/jbc. M112.437970)

Wei W, Dutchak PA, Wang X, Ding X, Wang X, Bookout AL, Goetz R, Mohammadi M, Gerard RD, Dechow PC et al. 2012 Fibroblast growth http://joe.endocrinology-journals.org DOI: $10.1530 / J O E-14-0440$
() 2015 Society for Endocrinology Printed in Great Britain 
factor 21 promotes bone loss by potentiating the effects of peroxisome proliferator-activated receptor $\gamma$. PNAS 109 3143-3148. (doi:10.1073/ pnas.1200797109)

Xu J, Lloyd DJ, Hale C, Stanislaus S, Chen M, Sivits G, Vonderfecht S, Hecht R, Li YS, Lindberg RA et al. 2009 Fibroblast growth factor 21 reverses hepatic steatosis, increases energy expenditure, and improves insulin sensitivity in diet-induced obese mice. Diabetes 58 250-259. (doi:10.2337/db08-0392)
Yuan C, Lin JZ, Sieglaff DH, Ayers SD, Denoto-Reynolds F, Baxter JD \& Webb P 2012 Identical gene regulation patterns of $\mathrm{T}_{3}$ and selective thyroid hormone receptor modulator GC-1. Endocrinology 153 501-511. (doi:10.1210/en.2011-1325)

Zhang CY, Kim S, Harney JW \& Larsen PR 1998 Further characterization of thyroid hormone response elements in the human type 1 iodothyronine deiodinase gene. Endocrinology 139 1156-1163. (doi:10.1210/endo.139.3.5849)

Received in final form 8 December 2014

Accepted 11 December 2014

Accepted Preprint published online 11 December 2014
Published by Bioscientifica Ltd. 